\title{
Structure of Wheat and Corn Farming: A Survey on Amik Plain Farmers
}

\author{
Mehmet Halis Koçer ${ }^{1, a}$, Ömer Konuşkan ${ }^{2, b, *}$ \\ ${ }^{1}$ Institute of Natural and Applied Sciences, Hatay Mustafa Kemal University, 31030 Hatay, Turkey \\ ${ }^{2}$ Department of Field Crops, Faculty of Agriculture, Mustafa Kemal University, 31030 Hatay, Turkey \\ *Corresponding author \\ A R T I C L E I N F O A B S T R A C T \\ Research Article \\ This study was conducted to identify the current problems of cereal crops like wheat and corn \\ producers and to suggest solutions for overcoming those problems in Amik Plain (Antakya, \\ Kirikhan, Kumlu, Reyhanli districts) in Hatay province of Turkey. In this study, the primary data \\ was obtained by face-to-face survey from 100 cereal producers in Amik plain. All variables are \\ Received : 02/09/2019 \\ Accepted : 10/08/2020 \\ given as frequency and percentage distribution, and numerical variables as mean. The survey \\ assessed the level of education of grain producers, the number of individuals in the farm, record \\ keeping, social security, crops (wheat and corn) growing area, yield, sowing and harvest date \\ ranges, property and leasehold land use, cultural practices and grain production. The data were \\ analysed using simple statistical analysis methods (frequency, averages, percentage distribution). \\ The results indicated that about $50 \%$ of the cereal producers had higher educational degree. It was \\ Keywords: \\ Wheat \\ determined that producers had an average of 12.3 ha of wheat and 15 ha of corn cultivated area. \\ Maize \\ Survey \\ Cultivation \\ Moreover, cereal production is well known as one of the cultural practices in the study area. The \\ main problem of grain producers is that the low cereal prices. In addition, the Turkish Grain Board \\ (TMO) does not purchase the production at the time of harvesting. Moreover, high production costs \\ Problems \\ and corn irrigation are considered other problems that cereal producers are facing.
}

\section{Introduction}

Cereals crops like rice (Oriza sativa), wheat (Triticum asetivum), corn (Zea mays), barley (Hordeum vulgare), sorghum (Sotghum vulgare), oat (Avene sativa), pearl millet (Panicum mileacceum), and foxtail millet (Setaria italica) are grown about half of the treated areas (720.6 million hectares), which is 1.4 billion hectares in the world (FAO, 2014). Wheat and corn crops are produced as annual cereals in any climatic and soil conditions in the world (Barutcular et al., 2017; Hossain et al., 2018; Yildirim et al., 2018). Wheat, which covered the most cultivated area among the cereals, is taken the first place of 220.1 million hectares of planting area. Corn is the world's largest cereal crop, playing a significant role in guaranteeing global food security (Abdelaal et al., 2017). Corn is secured the second position after wheat that covering 183 million hectares of cultivated area, and followed by rice with 163 million hectares. Globally, rice is one of the major cereals developed and grown over the world (Anis et al., 2019). The production trends of maize, rice and wheat are 1 billion tones, 741 million tons and 729 million tons, respectively (FAO, 2016).
In terms of planting area, 7.7 million ha of land are used for wheat production ( 21.5 million tons) which takes the first place in Turkey, and followed by barley and corn covering the area of 2.72 million ha and 639084 ha, respectively. The production figures of wheat, barley and maize are 21.5, 8.0 and 5.9 million tons against those production areas, respectively (TUIK, 2018).

The average yield of wheat and maize are $391 \mathrm{~kg} / \mathrm{da}$ and $1.087 \mathrm{~kg} / \mathrm{ha}$ respectively in Hatay, Turkey (TUIK, 2017). While the national average is $907.5 \mathrm{~kg} / \mathrm{da}$, and the average yield in the world is $566.4 \mathrm{~kg} / \mathrm{da}$ (FAO, 2014). Considering the fact that the cereals plays a central role in the human and animals feeding. In previous study, Kirtok, (1997) concluded that cereal crops play a significant role for foods and feedings. People living in developing countries cannot reach sufficient food sources originated from reach food. It causes malnutrition in the population of those countries. In this case, people tend towards to vegetable proteins such as wheat and corn. Various studies were performed on different agricultural cultivation and economical situation, previously (Koc et al., 2011; Parlakay et al., 2015a; Parlakay et al., 2015b; Y1lmaz et al., 
2015). In the future, the increase in temperature will cause a large amount of water loss in the soil and plants. Water shortage will result in a significant decrease in crop productivity. So, the main aim of this study was to identify problems in wheat and maize production, and to propose solutions to these problems for Amik plain of Hatay Province, Turkey.

\section{Material and Methods}

\section{Material}

The main material of this study was collected from the questionnaire of the agricultural enterprises who are engaged in the field of cereal cultivation in the research area. The data were collected through face-to-face interviews. The survey was conducted in spring 2015.

In the study, the data from FAO, TUIK, and Ministry of Food, Agriculture and Livestock were used as secondary data. The Ministry of Food, Agriculture and Livestock Hatay Provincial Area (Kırıkhan, Antakya and Reyhanlı), national and international information were taken into consideration for the research.

\section{Methods}

The determination of sample size, the villages that represent the research area in terms of agricultural techniques and natural conditions, where cereal production is common, were determined by the method of nontraditional sampling, and surveying of these villages was carried out by randomly selected enterprises.

Amik Plain grain (corn and wheat) producers and the data obtained by questionnaire were analysed by SPSS 22.0 program. Numerical variables are given as average, categorical variables are percentage distribution. The sample size is planned to be at least 100 Farmers. The questionnaire survey was conducted by considering the size of agricultural area of the location of area under investigation. In the study on maize agriculture which was made in the same region previously, the sample size was determined as 140 (Gözübenli et al., 2000) and in another study, the sample size was 67 (Öztekin, 2017). As a matter of fact, the sample size of 100 well-selected enterprises operating in a region with similar characteristics seems to be sufficient in agricultural management surveys (Yang, 1964).

\section{Result and Discussion}

\section{Data of The Hatay Province}

Surface area of Hatay Province is $5.827 \mathrm{~km}^{2}$ excluding lakes, $46.1 \%$ of provincial lands are consisted of mountains, $33.5 \%$ are consisted of plains and $20.4 \%$ are consisted of plateaus. The area size of Amik Plain is 105.388 ha and it is consisted $73 \%$ of the total plain area in Hatay province. The crops that are grown in the Amik Plain respectively are wheat, corn, cotton, potatoes, onion, sunflower and soybeans (Anonymous, 2016).Kaya and Budak (2018) revealed that, cotton, wheat and corn products has an important place in Amik Plain; (Kaya, 2017) also stated that Melon, onion, carrot, olive, apricot, spinach, tomato, vetch, potato, nectarine and parsley is formed the production pattern of the region.
Table 1. Age, education, livestock producer and insurance of the farmers

\begin{tabular}{l|c}
\hline \multicolumn{1}{c|}{ Age } & $\%$ \\
\hline $25-45$ & 38.4 \\
$46-65$ & 52.5 \\
$66-85$ & 7.1 \\
$86+$ & 2 \\
\hline \multicolumn{1}{c}{ Education } & $\%$ \\
\hline Literate & 13.7 \\
Primary & 22.1 \\
Middle School & 14.7 \\
High School & 26.3 \\
University & 23.1 \\
\hline \multicolumn{1}{c}{ Production method } & $\%$ \\
\hline Classical & 85.4 \\
Modern & 3.1 \\
Both & 11.5 \\
\hline \multicolumn{1}{c}{ Cropping System } & $\%$ \\
\hline Wheat & 7.1 \\
Corn & 1.2 \\
Wheat and forage crops & 1.2 \\
Wheat and maize & 22.4 \\
wheat, cotton, maize, vegetables & 51.80 \\
wheat, cotton, vetch & 16.5 \\
\hline
\end{tabular}

Table 2. Insurance, animal breeding, job of the farmers

\begin{tabular}{l|rr}
\hline & \multicolumn{1}{|c}{ No } & Yes \\
\hline Animal breeding(\%) & 89.7 & 10.3 \\
Insurance(\%) & 5.1 & 94.8 \\
Recording(\%) & 51.2 & 48.8 \\
Other job in Farming (\%) & 82.3 & 17.7 \\
Another job(\%) & 76 & 24 \\
\hline
\end{tabular}

When we look at product-based distribution of producers in terms of cultivation area usage; the average wheat cultivation area was $123 \mathrm{da}$, the number was changed by 10 to $500 \mathrm{da}$.

The average corn planting area was $150 \mathrm{da}$, and this number varies between 15 and $600 \mathrm{da}$. The average planting area was $62 \mathrm{da}$, and this number varies between 20 and 162 da. The average of the fruit planting area was $41 \mathrm{da}$. It is seen that this number changes between 10 and $95 \mathrm{da}$, the average cropping area of other crops is $135 \mathrm{da}$, and this number changes between 3 and 700 da.

It was determined that the vast majority of producers (60\%) were members of an agricultural establishment, about $70 \%$ of them use credit, and all receive product support (Table 2). The average cultivation area of 100 producers growing corn in Amik Plain is 185 da, yield is $1.332 \mathrm{~kg} / \mathrm{da}$ and price is determined as $0.71 \mathrm{TL} / \mathrm{kg}$ (Kaya and Budak, 2018).

The rotation distribution of the grain farmer is given in Table 1. Total $44 \%$ of the producers stated that they preferred wheat-cotton-corn-vegetable, $19 \%$ of wheatcorn, $6 \%$ of only corn, $1 \%$ of only wheat and $1 \%$ of wheatforage crops. Producuer usually prefer bread wheat varieties, and Sagittario, Basribey, Masaccio, Adana 99, Victoria, Stendal, and Golia are the most popular varieties of soft wheat. They also stated that they generally regarded the durum wheat as a local Karakılçık as bulgur which is traditional meal. 


\section{Sowing Time}

The dates of wheat planting period are produced in Table 3. According to the Table, $63 \%$ of the producers were planting in the period of 1-15 November, 33\% in November 15-30, and 4\% in December 1-30.

It has been determined that the sowing time of maize was largely done before May. Producers of $38 \%$ reply the sowing time of corn during 10-20 March, 24\% during 1-10 March, 7\% during 20-30 March, 17\% during 1-10 April, 14\% during 10-20 April (Table 3). Gözübenli et al. (2010) stated that the most suitable sowing time for maize should be done in May in Hatay ecological condition. It was determined that the sowing time of corn as the main crop should be set up in the coming years in Amik Plain.

\section{Irrigation}

Irrigation systems like drip, furrow irrigation, spring are practiced for irrigation in wheat and maize production area. In the surveyed area, the frequency of wheat irrigation was one times during the production period. Irrigation was generally used in reproductive period. While, $57 \%$ of wheat producers in the region do not irrigate wheat plantation, and $43 \%$ producers irrigate in wheat field. It is seen that the producers meet the irrigation water with $56 \%$ from their private well, $27 \%$ from the dam, $14 \%$ from the irrigation cooperative, and $3 \%$ from the neighbour (Table 4). Kaya (2017) investigated and reported that $53 \%$ of the producers of the Amik Plain participating wells, $23 \%$ of the river, $14 \%$ of the dam, $10 \%$ of both the well and the dam for irrigation. In Hatay, 206.553 hectares of agricultural land out of 275.578 hectares is suitable for irrigation. However, only 176.515 hectares of suitable irrigated land can be irrigated (Anonymous, 2014). Demirtaş et al., (2017) stated that $65 \%$ of producers are satisfied with irrigation in Hatay province.

\section{Fertilization}

The study results showed that growers use chemical fertilizer $(\mathrm{N}, \mathrm{P}, \mathrm{K})$ during the production period. Soil analysis were made by $79 \%$ corn producers and were not making the soil analysis by $\% 21$ farmers. Before sowing, producer prefer 15:15:15 (NPK) $6 \mathrm{~kg} / \mathrm{da}$, After emergence, they prefer ammonium nitrate $12 \mathrm{~kg} / \mathrm{da}$ inV2-V3 stage and lastly V6-V7 stage period they applied ammonium sulphate $5 \mathrm{~kg} / \mathrm{da}$ N. Nitrogen fertilizer $\left(250.48 \mathrm{~kg} \mathrm{ha}^{-1}\right)$ and $\mathrm{P}$ fertilizer $\left(28.32 \mathrm{~kg} \mathrm{ha}^{-1}\right)$ were applied during June, July and August.

While wheat producers of $79 \%$ were doing soil analysis, $21 \%$ were not analysing. Producer applied the phosphorous, potassium and nitrogen before sowing time about $6 \mathrm{~kg} / \mathrm{da}$, and they applied two times, first $12 \mathrm{~kg} / \mathrm{da} \mathrm{N}$ (Ammonium Nitrate), second $5 \mathrm{~kg} / \mathrm{da} \mathrm{N}$ (Ammonium sulphate) after tillering.

\section{Weed Control}

Almost all wheat producers were struggling the weed control (Table 6).

Table 3. Selecting seed of producer, wheat and maize sowing time of producers

\begin{tabular}{|c|c|c|c|c|c|c|c|}
\hline \multicolumn{3}{|c|}{ Selecting seed $(\%)$} & \multicolumn{5}{|c|}{ Sowing Time $(\%)$} \\
\hline & Wheat & Maize & Sowing date & Wheat & & $\begin{array}{l}\text { Maize } \\
\text { Main }\end{array}$ & Second \\
\hline Neighbouring field producer & 25.30 & 3.20 & October $15-30$ & 1.30 & March 1-10 & 24.10 & \\
\hline $\begin{array}{l}\text { Advice or recommendation } \\
\text { of commercial firm }\end{array}$ & 57.00 & 87.10 & November $1-15$ & 62.50 & March 10-20 & 37.90 & \\
\hline $\begin{array}{l}\text { Purpose of Governmental } \\
\text { agriculture organization }\end{array}$ & 12.70 & 8.10 & November $15-30$ & 32.50 & March 20-30 & 6.90 & \\
\hline University advice & 5.10 & 1.60 & $\begin{array}{l}\text { December } 15-30 \\
\text { December } 1-16\end{array}$ & $\begin{array}{l}1.30 \\
2.50\end{array}$ & $\begin{array}{l}\text { April 1-10 } \\
\text { April 10-20 } \\
\text { June 1-10 } \\
\text { June } 10-20\end{array}$ & $\begin{array}{l}17.20 \\
13.80\end{array}$ & $\begin{array}{l}69.00 \\
31.00\end{array}$ \\
\hline
\end{tabular}

Table 4. Water source and irrigation frequency of crops in Hatay province

\begin{tabular}{l|ccccc}
\hline \multicolumn{1}{c|}{ Water source and } & $\begin{array}{c}\text { Source use } \\
(\%)\end{array}$ & $\begin{array}{c}\text { Irrigation } \\
\text { frequency }\end{array}$ & $\begin{array}{c}\text { Wheat } \\
(\%)\end{array}$ & $\begin{array}{c}\text { Main Crop } \\
\text { Maize (\%) }\end{array}$ & $\begin{array}{c}\text { Second Crop Maize } \\
(\%)\end{array}$ \\
\hline Well & 42.0 & No & 57 & & 33 \\
Irrigation cooperative & 13.0 & Yes (1-2 times) & 43 & 5.0 & 67 \\
Dam & 5.0 & $3-5$ & & 76.7 & \\
Well and Dam & 2.0 & $5-7$ & & \\
& \multicolumn{7}{c}{$5-8$} & & \\
& & $7-11$ & & \\
\hline
\end{tabular}

Table 5. Amount of fertilization of cereals of producers in Hatay province

\begin{tabular}{l|cccc}
\hline & \multicolumn{3}{|c}{ Wheat } & \multicolumn{2}{c}{ Maize } \\
\cline { 2 - 5 } & $\begin{array}{c}\text { Before sowing } \\
(\mathrm{kg} / \mathrm{da})\end{array}$ & $\begin{array}{c}\text { After soving } \\
(\mathrm{kg} / \mathrm{da})\end{array}$ & $\begin{array}{c}\text { Before sowing } \\
(\mathrm{kg} / \mathrm{da})\end{array}$ & $\begin{array}{c}\text { After soving } \\
(\mathrm{kg} / \mathrm{da})\end{array}$ \\
\hline Phosphorous & 6 & & 6 & \\
Potassium & 3 & 12 & 6 & $12+5$ \\
Nitrogen & 6 & 6 & 6 \\
\hline
\end{tabular}


Farmers of $91 \%$ were using herbicide for maize. $4 \%$ farmers use herbicides before sowing, $86 \%$ used it after sowing and $10 \%$ after sowing and emerging. Around $87 \%$ of the wheat producers were struggling with insects, 93\% of them were fighting with aphids, $3 \%$ of cereal bugs, $4 \%$ of them were fighting against both aphids and cereals bugs.

Wheat producers of $97 \%$ struggle with diseases, which are $24 \%$ of septoria fighting, $19 \%$ of rust, $42 \%$ of both septoria and rust, $1 \%$ of riding and rusting, $14 \%$ septoria, rust and riding. It was determined that the vast majority of farmers were fighting the disease because of product losses.

Wheat producers of $47 \%$ observed the average yield between $500-600 \mathrm{~kg}, 40 \%$ between $600-700 \mathrm{~kg}$, $5 \%$ between $400-500 \mathrm{~kg}$, and $3 \%$ was between $300-400 \mathrm{~kg}$ (Table 9). It is recorded that the average wheat production in the Amik Plain is higher than the country's and world average.

Wheat producers of $47 \%$ observed the average yield between $500-600 \mathrm{~kg}, 40 \%$ between $600-700 \mathrm{~kg}$, $5 \%$ between $400-500 \mathrm{~kg}$, and $3 \%$ was between $300-400 \mathrm{~kg}$ (Table 9). It is recorded that the average wheat production in the Amik Plain is higher than the country's and world average.

\section{Grain Yield}

Main crop grain yields of corn of $1000-1200 \mathrm{~kg} / \mathrm{da}$ $1200-1400 \mathrm{~kg} / \mathrm{da}$ and $1400-\mathrm{kg} / \mathrm{da}$ were recorded by the farmers of $33.35 \%$ and $28 \%$ (Table9). The second crop of maize grain yields of $900-1000 \mathrm{~kg} / \mathrm{da}$, and $700-800 \mathrm{~kg} / \mathrm{da}$ were recorded by $60 \%$ and $40 \%$ farmers respectively.

\section{Marketing Management}

Wheat producers of $82 \%$ sell their product after harvest, and other wheat producers of $18 \%$ store it.

In Turkey, maize policy was introduced in 1941 as a result of the appointment of the Turkish Grain Board (TMO). Among wheat producers, $69 \%$ of the product were sold to the Merchant, $14 \%$ of product were sold to the TMO, $16 \%$ of product were sold to the others and $1 \%$ of product were sold to the feed factory in Hatay cereals producers (Table 10). Among the maize producers, 24\% of the product were sold to the Merchant, $23 \%$ of product were sold to the TMO, $13 \%$ of the product were sold to both Merchant and TMO, the rest were sold to starch factories.

In wheat production, $51 \%$ producers used rotation, $34 \%$ used easy cultivation, and $32 \%$ used both rotation and easy cultivation. İn maize production, $56.9 \%$ producers replied as they use rotation for easy farming, lots of money gain is $3.1 \%$, rotation is $29.2 \%$ and seeing next farmers is $4.6 \%$, all reasons is $6.2 \%$.

When asked about the futures of cereal grain producers in question, producers responded as increase of the product prices, irrigation water, improvement of the price of electricity and irrigation water, reduction of input costs, improvement of product sales price (Table 11). Hatay province has an important role in agriculture. It has a good soil and climatic conditions. Different products grow up in region, wheat and maize are the product group with the sowing area.
Table 6. Weed and Insect control of Producers in Hatay Province

\begin{tabular}{l|l|cc}
\hline & & Yes & No \\
\hline \multirow{2}{*}{ Weed control } & Wheat(\%) & 100 & \\
& Maize (\%) & 93 & 7 \\
\multirow{2}{*}{ Insect } & Wheat & 87 & 13 \\
& Maize & 100 & \\
\hline
\end{tabular}

Table 7. Disease control in wheat

\begin{tabular}{l|c}
\multicolumn{1}{c|}{ Disease and struggle type } & Fighting (\%) \\
\hline Chemical struggle & 97 \\
Septoria & 24 \\
Rust & 19 \\
Septoria and Rust & 42 \\
Riding & 1 \\
Septoria + Rusting + Riding & 14 \\
\hline
\end{tabular}

Table 8. Cereals harvest date in Hatay Province (\%)

\begin{tabular}{|c|c|c|c|}
\hline \multicolumn{4}{|c|}{ Harvest Time } \\
\hline Months & Wheat & $\begin{array}{c}\text { Main Crop } \\
\text { Mazie }\end{array}$ & $\begin{array}{c}\text { Second } \\
\text { Crop Maize }\end{array}$ \\
\hline 20-31 May & 65 & - & - \\
\hline 1-10 June & 35 & - & - \\
\hline 1-15 August & & 8.5 & - \\
\hline 15-30 August & & 52.5 & - \\
\hline 1-15 September & & 39.0 & - \\
\hline 1-15 October & & - & 24 \\
\hline 15-30 October & & - & 58 \\
\hline 1-15 November & & - & 12 \\
\hline Other months & & - & 6 \\
\hline
\end{tabular}

All the wheat producer is harvest with combine harvest.

Table 9. Cereals Grain Yield in Hatay (\%)

\begin{tabular}{c|ccc}
\hline \multicolumn{4}{c}{ Grain Yield } \\
\hline (kg/da) & Wheat) & $\begin{array}{c}\text { Main Crop } \\
\text { Maize }\end{array}$ & $\begin{array}{c}\text { Second } \\
\text { Crop Maize }\end{array}$ \\
$300-400$ & 3 & - & - \\
$400-500$ & 5 & - & - \\
$500-600$ & 40 & - & - \\
$600-700$ & 47 & - & - \\
$700-800$ & - & - & 40 \\
$900-1000$ & - & - & 60 \\
$1000-1200$ & - & 37 & - \\
$1200-1400$ & - & 35 & - \\
$1400-$ & - & 28 & - \\
\hline
\end{tabular}

Table 10. Cereals Marketing Management of Farmers

\begin{tabular}{l|cc}
\multicolumn{1}{c|}{ Product management } & Maize \% & Wheat (\%) \\
\hline Immediatly sell & 91,2 & 82 \\
Sold After storage & 4,4 & 12 \\
Partly storage and sell & 4,4 & \\
\hline
\end{tabular}

\section{Conclusion}

The farmer's family is five people on average. Education status of farmers is about $50 \%$ high school and university. Because of high education and large having field, it is determined that higher grain yield than in Turkey and in the World. But only $10 \%$ of farmers are livestock. Generally farmers use conventional methods for cereals production. 
Table11. Problems of producers about cereals growing and trade.

\begin{tabular}{|c|c|c|c|c|c|c|c|c|c|c|}
\hline \multirow{3}{*}{ Problems of Cereal Producer } & \multicolumn{10}{|c|}{ Wheat and Maize } \\
\hline & \multicolumn{10}{|c|}{ Order of importance } \\
\hline & \multicolumn{2}{|c|}{1} & \multicolumn{2}{|c|}{2} & \multicolumn{2}{|c|}{3} & \multicolumn{2}{|c|}{4} & \multirow[t]{2}{*}{5} & \\
\hline Product price $(\%)$ & 93 & 52 & 7 & 8 & - & 1 & - & & & \\
\hline Timely release of product price $(\%)$ & 2 & & 29 & & 69 & & - & & & \\
\hline Profit low $(\%)$ & 6 & & 71 & & 2 & & 3 & & & \\
\hline Storage problem, waste $(\%)$ & 1 & & 3 & 12 & - & 13 & 33 & & 75 & \\
\hline TMO does not get any crop for some years $(\%)$ & & 14 & & 47 & & 33 & & 6 & & \\
\hline High input prices $(\%)$ & & 6 & & 32 & & 57 & & 4 & & \\
\hline Less support (\%) & & & & & & & & & & 1 \\
\hline
\end{tabular}

More than $90 \%$ of producers have social security and are in active labor force. The averages of the field used as farm land for producers are 210 decares, the average of 61 decares used as for garden plants and and they have both the field and garden plants to determined 190 decares.

All area is irrigated but last years not to irrigation in maize expecially in second crop maize. For some years, due to heavy rainfall, wheat is under water. Farmers produce wheat on average 123 decares in Hatay. Maize area is 15 decare, Furits area is 41 decare, and others is 135 da. Farmers prefer soft wheats, which are Sagittario, Basribey, Masaccio, Adana99, Victoria, Stendal, and Golia. Besides this, a variety of Karakılçı, which is durum wheat, is also grown more than $60 \%$ of producers are sowing wheat cultivation between November 1-15. Wheat harvest time; \%65- 20-31 in May, \%35- in June.

Almost $60 \%$ of the producers do not irrigate wheat production, while $43 \%$ irrigate with 1 to 2 irrigation depending on the drought. Around 56\% of the producers take irrigation water from their well. Production cost is increased due to high electricity cost in irrigation water made from deep wells. In order to reduce the cost of cereals, the Reyhanlı Dam which is in the construction stage should be completed as soon as possible. The problems that wheat growers have about wheat growing and trading are the product price, the ineffective disclosure of product price, the low profit margin and the storage problem-the percentage of waste.

Maize farmer of $76 \%$ prefer main crop. Generally they sow in March as main crop. And harvest time is 15-30 Augst. In $60 \%$ cases, the second crop harvest time is 15 30 October. Irrigation number of main crop is $5-8,70 \%$ as second crop is irrigated 7-9 number. Weed control is good. About $91 \%$ of farmers are used a herbicide. All the producers used a insecticide for controlling insects. Grain yield is higher than Turkey and in the world. Almost all farmers or producers sell their products.

\section{Acknowledgements}

This study was prepared from Mehmet Halis KOÇER's thesis titled "Determination of Cereals Cultivation and Problems in Amik Plain Conditions" in Hatay Mustafa Kemal University

\section{Refrences}

Abdelaal AAKh, Hafez YM, EL Sabagh A. 2017. Ameliorative effects of abscisic acid and yeast on morpho-physiological and yield characters of maize (Zea mays L.) plants under water deficit conditions. Fresenius Environmental Bulletin, 26 (12): 7372-7383.
Anis G, Hassan H, El-Sherif A, Saneoka H, EL Sabagh A. 2019. Evaluation of New Promising Rice Hybrid and Its Parental Lines For Floral, Agronomic Traits and Genetic Purity Assessment. Pakistan Journal of Agricultural Sciences, 56(3): 567-576.

Anonim. 2004. TUIK, 2004. 2001 genel tarım sayımı, tarımsal işletmeler (haneli). T.C. Başbakanlık devlet istatistik enstitüsü, Ankara. www.tuik.gov.tr erişim tarihi: 02/07/2017.

Anonim. 2014. Tarım ve Orman Bakanlığı Hatay İl Müdürlüğü, Erişim Tarihi: 15.04.2017.

Anonim. 2016. Gıda Tarım Hayvancılık Bakanlığı Hatay tarım il müdürlüğü brifing raporu. Erişim tarihi: 01/07/2017.

Barutcular C, EL Sabagh A, Koç M, Ratnasekera D. 2017. Relationships between Grain Yield and Physiological Traits of Durum Wheat Varieties under Drought and High Temperature Stress in Mediterranean Conditions. Fresenius Environmental Bulletin 26 (4): 4282-4291.

Demirtaş B, Dağıstan E, Yılmaz Y, Tapkı N. 2017. Agricultural Water Mangement Problems in Hatay. Turkish Journal of Agriculture-Food Science and Technology. 5(4): 416-424.

FAO. 2016. Food and agriculture organization of the united nations web sayfasi. (http://www.fao.org) erişim tarihi: 02/07/2017.

Gözübenli H, Şener O, Konuşkan Ö, Şahinler S, Kılınç M. 2000. Hatay'da mısır tariminin genel durumu, sorunlari ve çözüm yollari. Mustafa Kemal Üniversitesi Ziraat Fakültesi Dergisi 5 (1-2): 41-48.

Gözübenli, H., Konuşkan, Ö., Aktürk, H., 2010. Farkli ekim zamani ve bitki sikliklarinda yetiştirilen misır çeşitlerinde verim ve verimle ilişkili bazi özelliklerin belirlenmesi. Mku Ziraat Fakültesi Dergisi, 15 (1): 1-10.

Hossain MM, Hossain A, Alam MA, EL Sabagh A, Khandakar Faisal Ibn Murad, Haque MM, Muriruzzaman M, Islam MZ, Das S. 2018. Evaluation of fifty spring wheat genotypes grown under heat stress condition in multiple environments of Bangladesh. - Fresenius Environmental Bulletin 27 (9): 5993-6004.

Kaya A. 2017. Amik Ovasında mısır üreticilerinin damla sulama yöntemini benimsemesine etki eden faktörler, Çukurova Üniversitesi Fen Bilimleri Enstitüsü Yüksek lisans tezi, Adana.

Kaya A, Bostan Budak D. 2018. Amik ovas1 misır üretim potansiyeli, ÇÜ Fen Bilimleri Enstitüsü Fen ve Mühendislik bilimleri Dergisi, Cilt 36, Sayı 7.

Kirtok Y. 1997. Field Crops Cool and Warm Season Cereals. Cukorva University, Adana.

Koc B, Gul M, Parlakay O. 2011. Determination of Technical Efficiencyin Second Crop Maize Growing Farms in Turkey: A Case Study For The Mediterennean in Turkey. Asian Journal of Animal and Veterinary Advances 6(5): 488-498. Doi:10.3923/avaja.2011.488.498

Öztekin M. 2017. Determination of Socio-econumic situation and problems encountered on wheat cultivation og growers in the villages of Adana Province Karataş districs. Mustafa Kemal University, master thesis, p. 
Parlakay O, Semerci A, Celik AD. 2015a. Estimating technical efficiency of dairy farms in Turkey: a case study of Hatay Province. Custos e Agronegocio Online, 11(1): 106-115.

Parlakay O, Celik AD, Kizıltuğ T. 2015b. Enviromental issues caused by agricultural production solution proposals in Hatay Province. Ziraat Fakültesi Dergisi, Mustafa Kemal Üniversitesi, 20(2): 17-26.

Tiryakioğlu M, Demirtaş B, Tutar H. 2017. Türkiye'deki buğday veriminin karşılaştırılması. Hatay ve Şanliurfa illeri örneği, Süleyman Demirel Üniversitesi Ziraat Fakültesi Dergisi 12 (1): 56-67.

TUIK. 2018. Türkiye istatistik kurumu, www.tuik.gov.tr erişim tarihi: 02/07/2017.
Yang WY. 1964. Zirai işletmecilikte tetkik ve araștirma metotlari (çeviren M. Talim), E.Ü. Matbaasi, izmir.

Yıldırım M, Barutcular C, Koc M, Dizlek H, EL Sabagh A, Hossain A, Akinci C. 2018. Assessment of the grain quality of wheat genotypes grown under multiple environments using gge biplot analysis. Fresenius Environmental Bulletin, 27(7): 4830-4837.

Yılmaz Y, Semerci A, Tapk1 N, Dağıstan E, Konuskan Bozdogan D. 2015. Consumers knowledge, attitudes and beheviyor assesment abaout food safety; The case study of Hatay Province of Turkey. Turkish Journal of AgricultureFood Science and Technology. 3(8): 672-679. 